\title{
ROMAN-PERIOD MYSTERY CULTS AS THE FOCAL POINTS OF CURSING RITUALS?
}

\begin{abstract}
Summary: The recently published curse tablets from the sanctuary of Magna Mater in Mainz, from the hero shrines of Opheltes and Palaimon, and from the sanctuary of Demeter and Kore, as well as a single curse tablet from late Roman Antioch invoking the "secret names" of the Samothracian deities, all suggest some connection between mystery religions and cursing. Two possible explanations are explored: (i) because initiates had special access to divine powers, their curses were thought to be especially powerful; or (ii) because these new discoveries fit two traditional types of defixiones: those placed in or at the graves of those violently killed, like Opheltes, or those placed in sanctuaries of female divinities, like Demeter, whose myths focus on the loss and return of a loved one from Hades.
\end{abstract}

Key words: mystery religion, mystery cult, curse tablet, defixio, prayer for justice, burning, melting, lead, lamps, Magna Mater, Mainz, Opheltes, Palaimon, Demeter, Kore, Acrocorinth, Antioch, Samothrace, Dioscuri

The publication of lead curse tablets from sanctuaries of various mystery cults over the last two decades calls for investigation. Twenty years ago one could still write that defixiones were generally found in graves, underground bodies of water, or sanctuaries of female goddesses, especially Demeter and Kore. Since then, however, the publication of the curse tablets from the sanctuary of Magna Mater in Mainz, from the hero shrines of Opheltes and Palaimon, and from the sanctuary of Demeter and Kore on the Acrocorinth suggests a possible revision in our understanding, as does the single curse tablet from late Roman Antioch invoking the "secret names" of the Samothracian deities, who were also the central focus of a mystery cult. In what follows, we shall review these new texts, paying close attention to their archaeological context and exploring two possible explanations: (i) that initiates did indeed have special access to these superhuman forces, in ways that allowed their curses to be especially powerful; or (ii) that these new discoveries can still be explained as belonging to two of the three traditional types mentioned above: those placed in or at the graves of the dead, or those placed in sanctuaries of female divinities, like Mater Magna or 
Demeter, whose myths focus on the loss and return of a loved one from Hades. My conclusions provide a largely negative answer to the question posed in the title, but as we shall see, the parallels between the curse rituals on the Acrocorinth and those at Mainz are highly suggestive.

\section{SAMOTHRACE}

Before we begin with the curses, however, we should recall similar kinds of crossover between mystery cults and another branch of ancient magic: incantations and amulets used to protect or heal. It is well known, for example, that two of the socalled Orphic Gold Tablets were found in Roman period amulet-cases; ${ }^{1}$ and we now know, thanks to the publication of the Getty Hexameters, that the powerfully protective incantation known in Roman times as the Ephesia grammata was originally a hexametrical narrative that is probably connected with some Sicilian cult of Demeter and Kore, perhaps even a mystery cult. ${ }^{2}$ In the Roman period, too, we have evidence for the use of images of Mithras and the bull as amulets, as well as inscribed prayers to mystery gods asking for help or salvation. ${ }^{3}$ Such developments are not, of course, surprising. Walter Burkert pointed out many years ago that initiates in mystery cults, in addition to the benefits they expected concerning the afterlife, also imagined that they would receive special protection or success in this world; the Samothracian initiates provided him with his strongest case, because they were said to wear, for instance, purple sashes that protected them from storms at sea and magnetic iron rings that may have also been used as amulets. ${ }^{5}$ We also know from a passage in Aristophanes

${ }^{1}$ For the 4th cent. BCE Petelia tablet discovered rolled up in a 2 nd cent. CE amulet case, and for the 2nd cent. CE tablet written for a woman named Caecilia Secundina and found in a case of the same date, see Zuntz, G.: Persephone. Oxford 1971, 279-284 and FARAONE, C. A.: Mystery Cults and Incantations: Evidence for Orphic Charms in Euripides' Cyclops 646-48? Rheinisches Museum 151 (2008) 127-142, and FARAONE, C. A.: A Socratic Leaf-Charm for Headache (Charmides 155b-157c), Orphic Gold Leaves and the Ancient Greek Tradition of Leaf Amulets. In DiJKSTRA, J. - KROESEN, J. KUIPER Y. (eds): Myths, Martyrs, and Modernity. Studies in the History of Religions in Honour of Jan N. Bremmer. Leiden 2009, 145-166.

2 JORDAN, D. R. - KOTANSKY, R. D.: Ritual Hexameters in the Getty Museum: A Preliminary Edition. ZPE 178 (2011) 54-62 and FARAONE, C. A. - OBBINK, D. (eds): The Getty Hexameters: Poetry, Magic and Mystery in Ancient Greek Selinous. Oxford 2013.

${ }^{3}$ FARAONE, C. A.: The Amuletic Design of the Mithraic Bull-Wounding Scene. Journal of Roman Studies 103 (2013) 96-116 and FARAONE, C. A.: Twisting and Turning in the Prayer of the Samothracian Initiates (Aristophanes Peace 276-79). Museum Helveticum 61 (2004) 30-50.

4 The scholia to Apollonius Rhodius Argonautica 1.917-918 connect these purple sashes with the veil that Leucothea gave to Odysseus, which he bound around his torso to save himself from drowning. Linen may, in fact, have been an Egyptian feature. PGM IV 1071-1084, for example, recommends inscribing a protective spell on "the linen cloth from a Harpocrates statue". DIELEMAN, J.: The Materiality of Textual Amulets in Ancient Egypt. In Boschung, D. - Bremmer, J. N. (eds): The Materiality of Magic. Munich 2015, 23-58 traces a long handbook tradition in Pharaonic Egypt of inscribing linen amulets with images, tying knots in them, and then wearing them on the neck.

${ }^{5}$ The literary sources all date to the Roman period or later, but dozens of rings have been found (many still unpublished) in the sanctuary, and they date to all periods; see BURKERT, W.: Concordia 
that Samothracian initiates were taught special prayers that could avert catastrophic storms at sea. The special power of the prayers of the Samothracian initiates seems, in fact, to have been knowledge of the individual names of the deities that were hidden behind the anonymous and plural designation of these gods as "the Great Gods" or the "Samothracian Gods." 6

A dim memory of their special protective power at sea seems to survive in a recipe from a Demotic handbook that quotes a long magical name and then boasts: "This name, you say it before a ship that is about to founder, on account of the names of Dioscorus (i.e. the Dioscuri), which are within, so that it is safe."7 The Dioscuri were, in fact, sometimes numbered among the Samothracian gods. ${ }^{8}$ Samothrace also provides us with a good place to begin talking about the connections between mystery cults and curses, because the secret names of the Samothracian gods are apparently invoked in a recently published curse from the hippodrome at Antioch: ${ }^{9}$

O Arxieris, Kadmilos, Arxierissa, Kadmilos, Phersephone, Zeus, come, mimireusata kharsith me lentas Poseidon, Damnameneus, (4) Ethetais, Dioskouros, ... Arxieria, Arxianassa, Demeter, Dionysos, ... of the Korybantes, Zeus, Plouten, Zeus, ... (8) Hekate, Zeus, ... son of the Divider, Dionysos, Zeus, Poseidon, Plouten, Demeter, Merka[]puas Axierexar, Arxi $<e>$ rissa, Arxiax, (12) ...

This list of powerful gods and magical names continues, with some repetitions, for another thirty-two lines, and then ends with the prayer: "Bind, destroy, and completely subdue the horses of the Blue faction." Of great interest are all of the italicized names above, especially those that appear at the very start of the invocation: Arxieris, Kadmilos, Arxierissa, Kadmilos. As Alex Hollmann points out in his excellent commentary, these names are quite similar to the names of the four Samothracian gods given by the Hellenistic mythographer Mnaseas, names which he equated, moreover, with four well-known Greek gods, who are of course connected with the mystery rites celebrated at Eleusis and elsewhere: ${ }^{10}$

Discours: The Literary and Archaeological Evidence on the Sanctuary of Samothrace. In MARINATOS, N. HÄGG, R. (eds): Greek Sanctuaries: New Approaches. London 1993, 178-191, here 187-188 and BlAKELY, S.: Toward an Archaeology of Secrecy: Power, Paradox, and the Great Gods of Samothrace. Archeological Papers of the American Anthropological Association 21 (2012) 49-71, here 61-63. The fact that they were magnetic also suggests that they were amuletic, for magnetite itself was often used as an amulet; see FARAONE, C. A.: The Transformation of Greek Amulets in Roman Imperial Times (Philadelphia 2018) 92-93.

${ }^{6}$ FARAONE: Twisting (n. 3).

${ }^{7}$ PDM XIV 1060-1061, quoted in the GMPT translation of Janet Johnson, who makes the connection with the Dioscuri.

${ }^{8}$ Hollmann, A.: A Curse Tablet from the Circus at Antioch. ZPE 145 (2003) 67-82, here 69, line 4

${ }^{9}$ Hollmann (n. 8).

${ }^{10}$ Mnaseas (3rd cent. BCE) FGrHist III 154 F27 (= Sch. Apollonius Rhodius 1. 917). Full discussion in HOLLMANN (n. 8). 


\begin{tabular}{lll} 
Mneseas & Mneseas' Equations & Antioch Tablet \\
\hline Axieros & $=$ Demeter & Arxieris \\
Axiokersa & $=$ Persephone & Arxierissa \\
Axiokersos & $=$ Hades & Arkhieres(?) \\
Kadmilos & $=$ Hermes & Kadmilos
\end{tabular}

And, as we saw in the Demotic incantation for protecting a ship at sea, the name "Dioskouros" also appears on the Antioch curse tablet.

The late antique date of the Antioch curse makes it unlikely, of course, that its author was a Samothracian initiate, although it might be the case that this particular curse formula was created much earlier. But even if it was the invention of some Roman-period scribe or practitioner, it seems most probable that the names of the Samothracian gods were inserted into this text by the same analogies offered by Mnaseas: they were simply thought to be the occult names of four Greek gods frequently named on Greek curse tablets. On the other hand, the fact that the Samothracian names are the first to be listed on the tablet may be significant. Compare, for example, how the names of some similarly standard Greek cursing deities are "translated" on a series of lead tablets found in Egypt that adapt an originally Greek formula to their new environment by adding Eastern or occult names after the Greek ones almost as if they were epithets or translations: ${ }^{11}$

Pluto usemigadôn, and Kore Persephone Ereshkigal, and Adonis also called barbaritha and Hermes Katachthonius Thoth phôkenepseu arektathou and mighty Anubis psêriphtha, who holds the keys to Hades.

\section{misonktaik}

In this invocation, at least, we can see that the first-named in each section are Greek gods with clear connections to the underworld, who are then further identified as or equated with eastern gods, such as Ereshkigal or Thoth, or labeled with magical or nonsense words like usemigadôn or barbaritha. ${ }^{12}$ If this kind of logic was at play in the evolution of the Antioch curse, it could well be that the formula originally invoked the Samothracian gods and that the other names were added later.

\section{HEROIC SHRINES}

Mystery cults were also a popular feature at some heroic sanctuaries: the sanctuary of Palaimon at Isthmia, for example, was thought to be the burial place for the child-hero,

${ }^{11}$ Using the archetype developed by MARTINEZ, D.: P. Michigan XVI: A Greek Love Charm from Egypt [American Studies in Papyrology 30]. Atlanta 1991, 113-117 from a family of six different texts, including a recipe from $P G M \mathrm{IV}$.

${ }^{12}$ FARAONE, C. A.: The Ethnic Origins of a Roman-Era Philtrokatadesmos (PGM IV 296-434). In Mirecki, P. - MEYER, M. (eds): Magic and Ritual in the Ancient World. Leiden 2002, 319-343, here 324-325. 
after he was drowned at sea and then rescued by a dolphin. ${ }^{13}$ Almost nothing is known about the Isthmian cult prior to the Roman period, but within a century after the destruction of the sanctuary by Mummius, we have a great deal of evidence for nocturnal rites that later authors refer to as "mysteries" or "initiations". 14 These rites included the burning of entire bulls in rectangular fire pits, which also yielded large lamps that are unique to this sanctuary and were probably designed to provide light for long nighttime celebrations. The only known curse tablet dedicated to Palaimon dates, however, much earlier - to the late 4th century BCE - and was found in another shrine in Athens dedicated to both Palaimon and Pankrates: ${ }^{15}$

Before Palaimon I bind down Aristophanes and ... [six names follow]. I beseech you, o Palaimon: become a punisher (timôros) of those I have listed for you and to the judges (i.e. in a forthcoming lawsuit) let them seem to say unjust things and for the witnesses may what they do be useless. And bind their hands, tongue, soul, and works, because they both do and say unjust things....

This curse, then, aims at preventing a man named Aristophanes and six others from being successful in an upcoming lawsuit in which the author of the curse was undoubtedly an opponent. ${ }^{16}$ Palaimon is invoked as a "punisher" for those who speak and act unjustly, a role that he perhaps also held in the mysteries, at which, according to Pausanias, initiates allegedly swore an especially powerful oath, with dire consequences for those who broke it. ${ }^{17}$

The putative grave of another child-hero, Opheltes, was also situated within a panhellenic sanctuary, this one for Zeus at Nemea, and it also yielded some curse tablets. The texts themselves all seem to use the same formula for dissuading one person from being attracted erotically to another, as we see in this example, the bestpreserved of the lot: ${ }^{18}$

${ }^{13}$ GeBhARD, E. R.: Rites for Melikertes-Palaimon in Early Roman Corinthia. In ScHOwALter, D. N. - FRIESAN, S. J. (eds): Urban Religion in Roman Corinth: Interdisciplinary Approaches [Harvard Theological Studies 53]. Cambridge, MA 2005, 165-203 and PACHE, C. O.: Baby and Child Heroes in Ancient Greece. Urbana 2004.

${ }^{14}$ Gebhard (n. 14) and Koester, H.: Melikertes at Isthmia: A Roman Mystery Cult. In BALCH, D. L. - Ferguson, E. - MeEKS, W. A. (eds): Essays in Honor of Abraham J. Malherbe. Minneapolis 1990, 355-366.

${ }_{15}$ JORDAN, D.: An Athenian Curse invoking Palaimon. In MATHAIOU, A. P. - POLINSKAYA, I. (eds): MIKPO $I E P O M N H M \Omega N$ : MEAETE $\Sigma$ EI $\Sigma$ MNHMHN Michael H. Jameson. Athens 2008, 133-144.

${ }^{16}$ VERSNEL, H. S.: Prayers for Justice East and West: Recent Finds and Publications. In GoRDON, R. - MARCO SIMÓN, F. (eds): Magical Practice in the Latin West: Papers from the International Conference held at the University of Zaragoza, 30 Sept. - 1 Oct. 2005. Leiden 2010, 275-356, here 311-312, quoting the description of Jordan SGD II no. 14.

${ }^{17}$ Pausanias Corinth 2. 1. 3: "Further on, the pine still grew by the shore at the time of my visit, and there was an altar of Melicertes. At this place, they say, the boy was brought ashore by a dolphin; Sisyphus found him lying and gave him burial on the Isthmus, establishing the Isthmian games in his honor." (Jones, LCL)

${ }^{18}$ BRAVO, J.: Erotic Curse Tablets from the Heröon of Opheltes at Nemea. Hesperia 85 (2016) 121-152, no. 1. 
I turn Euboula away from Aineas: from his face, from his eyes, from his mouth, from his chest, from his soul, from his belly, from his erect penis, from his anus, from all his body. I turn Euboula away from Aineas.

These curses seem to be of a Hellenistic date or earlier, but because all of them were found in disturbed archaeological contexts, one or more may in fact have been inscribed in Roman times. Unlike the curse from the Athenian shrine to Palaimon, these curses invoke neither the hero Opheltes himself nor any other gods, nor were they placed in or very close to his "tomb", as we might expect. ${ }^{19}$ There is, moreover, no evidence that mysteries were performed at this sanctuary and I think that Jorge Bravo is correct in saying that curses were placed in this sanctuary because the child hero Opheltes, like Palaimon, was horribly killed and therefore he fits perfectly the profiles of the two types of dead most often invoked in curses: those who died prematurely and those who were violently killed.

\section{DEMETER AND KORE}

There are also a few cases where mystery cults of the Demeter-Kore type may have been the focus of personal cursing rituals. One case that can be dismissed rapidly are the curse tablets found at Cnidus and a few other places, which were apparently set up publicly in a sanctuary of Demeter-Kore for viewing by female worshippers, probably during the Thesmophoria. ${ }^{20}$ These curses are concerned with unsolved crimes, such as theft or slander, or simply aim at revenge, and they were not, as far as we can tell, rolled up or placed underground, nor do they call on Kore by her chthonic name Persephone; rather, they are focused entirely on conflict resolution in the upper world, by publicizing the alleged crimes before the women of the city after they have assembled for the Thesmophoria. ${ }^{21}$ The recently published curses of early imperial date from the sanctuary of Demeter and Kore on the Acrocorinth were, however, deposited somewhat secretly in the lower terrace of the sanctuary in the context of nocturnal celebrations that we often connect with mystery celebrations. ${ }^{22}$ The two earliest tablets (see nos 130-131 on the eastern edge of the plan in Figure 1) curse a woman named Maxima Pontia and were found in a former dining room that by the first quarter of the 1st century CE had apparently been converted to a kind of ritual space with two large incense burners. ${ }^{23}$ The largest group of curses, however

\footnotetext{
${ }^{19}$ Tablets 2 and 3 were found about 10 meters to the south of the "tomb", and the other two the same distance away to the northwest; see BRAVO (n. 19) fig. 2.

${ }^{20}$ FARAONE, C. A.: Curses, Crime Detection and Conflict Resolution at the Festival of Demeter Thesmophoros. Journal of Hellenic Studies 131 (2011) 25-44.

${ }_{22}^{21}$ FARAONE: Curses (n. 20).

${ }^{22}$ I am grateful to Ron Stroud and Nancy Bookidis for their comments on an earlier draft of this section.

${ }^{23}$ STROUD, R. S.: The Sanctuary of Demeter and Kore: The Inscriptions [Corinth 18.6]. Princeton 2013, 140 fig. 93 and additional written comments from N. Bookidis.
} 


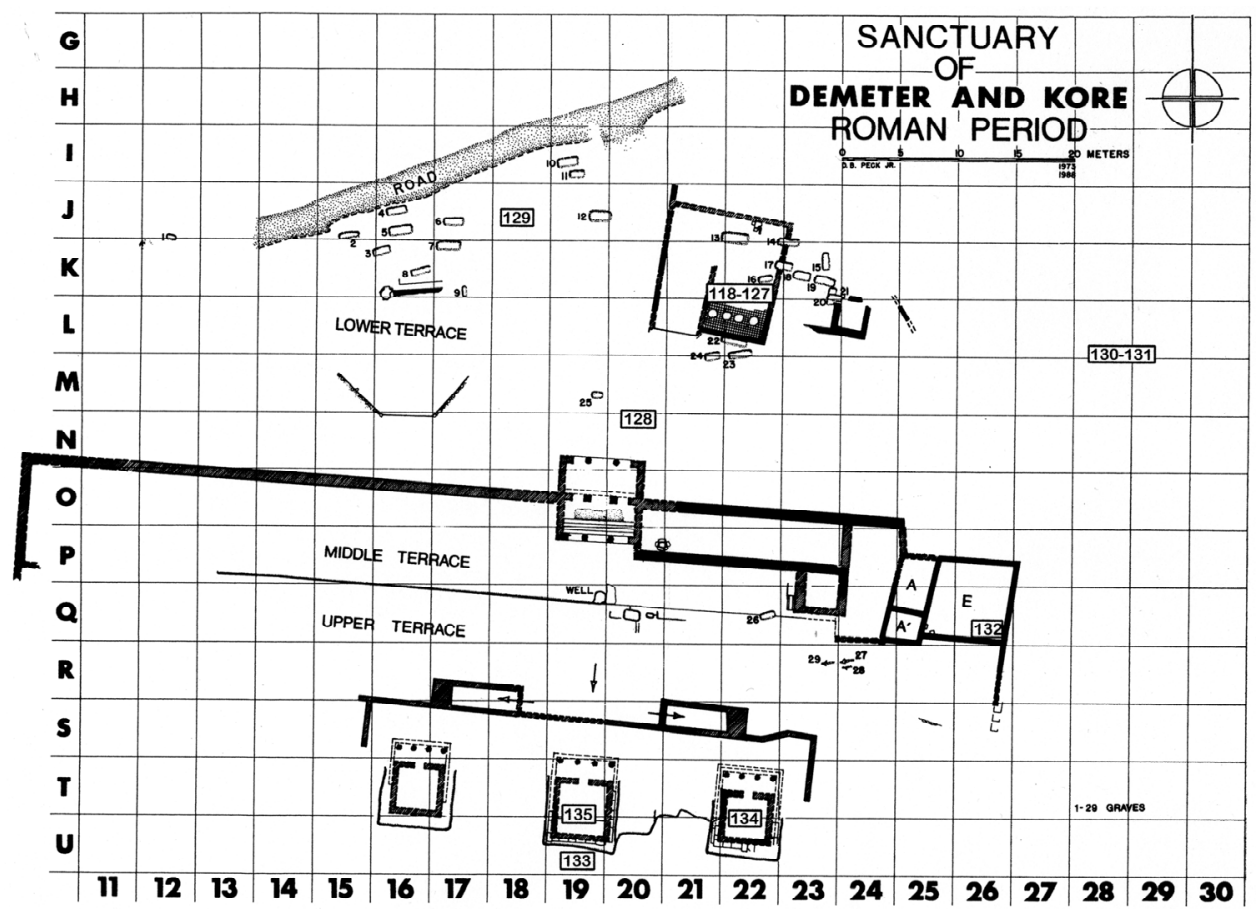

Fig. 1. Plan of the Sanctuary of Demeter and Kore on the Acrocorinth (after STROUD [n. 24] 140 fig. 93)

- these are nos 118-129 in the top center of the plan -, were found in or near a small room (Room 7), which was part of another reused building that sat just inside of the sanctuary, quite close to the main entrance, and which yielded curses in three distinct chronological phases: nos 118-120 were found in the lowest level in the rubble packing; six others (nos 121-126) were found in the next level on top of a thick clay floor dated by coins and pottery to the last quarter of the 1st century CE (for placement see Figure 3), while a single curse (no. 127) was found in the third level on top of a tile floor of late 2nd-century date. Two other curses, nos 128-129, were found in late Roman fill about 10 meters away and are very similar to those found within Room 7, from which they, too, probably originated. ${ }^{24}$

At all three of these levels in Room 7, the excavators also found fragments of many small lamps, large incense burners (identical to those found with the curses against Maxima Pontia), and small thin-walled cups or pitchers of a special type. ${ }^{25}$ Neither place, however, yielded animal bones or any other other signs of burnt sacrifice, suggesting that beginning in the mid-1st century CE these cursing ceremonies - perhaps the earliest cultic activity at the sanctuary after the sack of Corinth - took

\footnotetext{
${ }^{24}$ STROUD (n. 23) 152.

${ }^{25}$ STROUD (n. 23) 139-146.
} 


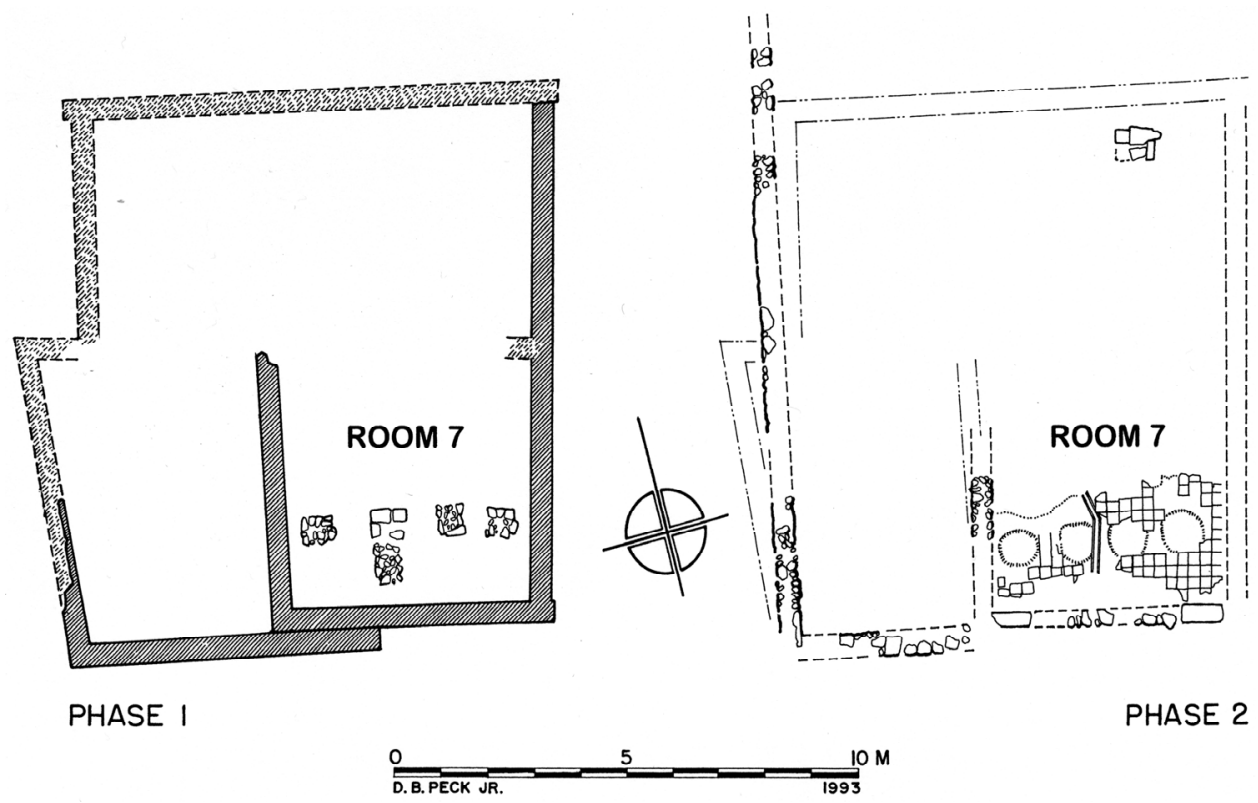

Fig. 2. Plans of Room 7 of the Sanctuary of Demeter and Kore on the Acrocorinth (after STROUD [n. 24] 141 fig. 94)

place in lamplight, either at night or in windowless rooms, and also involved the burning of incense and - in Room 7, at least - the pouring of libations. These curses (as you can see in Figure 2) were found at the southern end of Room 7, where four stone blocks seem to have served as the bases of low altars. Since this room was roughly 25 square meters in area, this space could only accommodate a handful of worshippers at a time. These four altars were eventually hidden at the end of the 2 nd century (compare Phases 1 and 2 in Figure 2), when the ground level was raised and a new tile floor was installed, but the altars were apparently too important to be forgotten: four shallow pits were dug through the tile-floor at spots roughly centered above the stone blocks, but without revealing them. The pits - as well as the drain running between the second and third pit - suggest, of course, that libations continued to be offered in this part of the room. ${ }^{26}$

Although we do have evidence that some kind of mystery rites were celebrated on the Acrocorinth before the arrival of the Romans, and although these rites were presumably revived when the sanctuary was rebuilt, to date there is no firm evidence for such continuation. ${ }^{27}$ But if these mystery celebrations did indeed persist, we should ask ourselves whether there is any evidence that they encouraged or included

\footnotetext{
${ }^{26}$ We see the same thing at Samothrace, where, after the monumentalization of the site in the Hellenistic period, apertures were left in the floor to allow libations to be poured in the right spots.

${ }^{27}$ STROUD (n. 23) 156.
} 

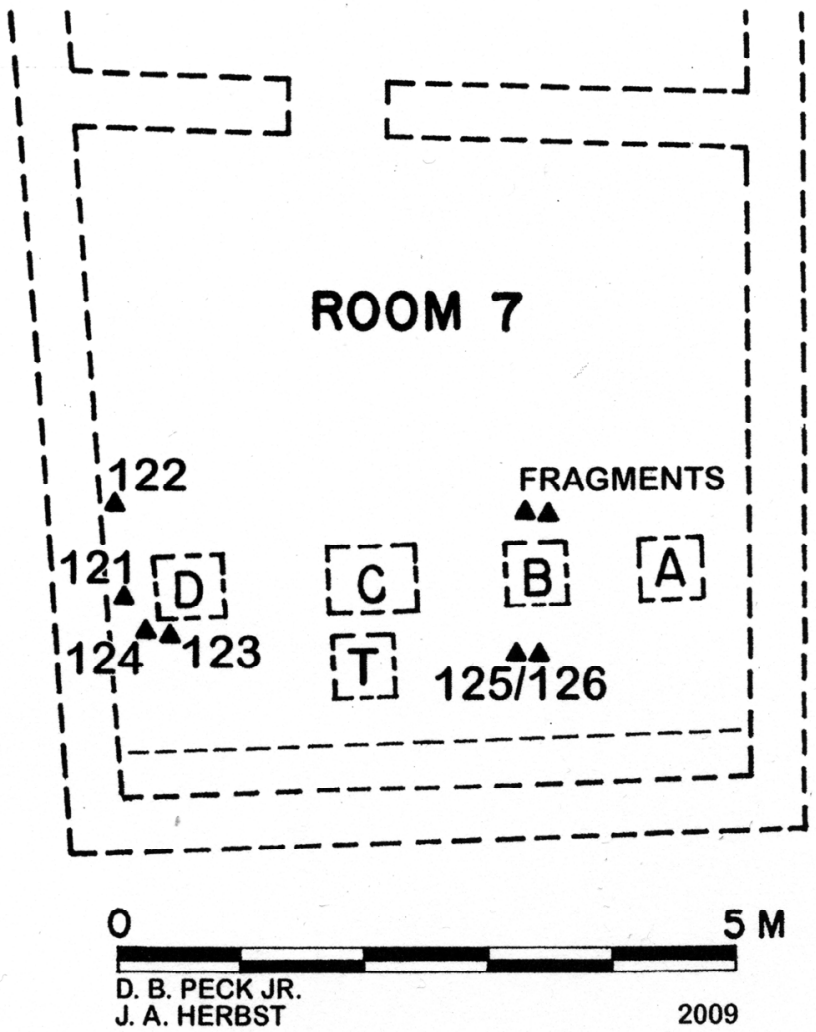

Fig. 3. Plan of Room 7 of the Sanctuary of Demeter and Kore on the Acrocorinth (after STROUD [n. 24] 141 fig. 95b)

the deposit of curse tablets. The presence of many lamp fragments does, of course, suggest some kind of nocturnal or otherwise occult ceremony, like that performed as part of the mysteries of Palaimon at Isthmia, but the gods invoked on the tablets from Room 7 are not, in fact, Demeter and Kore, as we might expect; see, for example, this elaborate curse against Karpime Babbia: ${ }^{28}$

I entrust and consign Karpime Babbia, weaver of garlands, to the Fates who exact justice, so that they may punish her acts of insolence, to Hermes of the Underworld, to Earth, so that they may overcome and completely destroy the psyche, the heart, the mind and the wits of Karpime Babbia, weaver of garlands....

The full list of deities who appear in the Acrocorinth curses does not, in fact, even include Demeter and Kore: ${ }^{29}$

\footnotetext{
${ }^{28}$ STROUD (n. 23) no. 126.

${ }^{29}$ STROUd (n. 23) 84.
} 
Necessity (Anangkê): nos 122, 125, and 126

Avenging Goddesses and Gods (Theai Aleiterai/Theoi Aleiteroi): 124

Earth $(G \hat{e})$ and "the children of Earth": 125-126

Hermes of the Underworld (Chthonius): 125-126

The Fates Who Exact Justice (Moirai Praxidikai): 125-126

Lord and the Lord Gods of the Underworld (Kyrios and Kyrioi Theoi

Katachthonioi): 127

Although the two most important goddesses of the sanctuary do not appear, all of these other divinities are, in fact, appropriate inhabitants of a chthonic sanctuary and therefore quite useful for cursing. Bookidis and Stroud have, moreover, identified the easternmost temple in the upper terrace - a temple that is equal in size to the temple of Demeter - as that of the "Fates Who Exact Justice" (the Moirai Praxidikai), who appear on two of the curses. ${ }^{30}$ Pausanias, moreover, speaks of a temple of Anangke and Bia near the sanctuary of Demeter on the Acrocorinth. ${ }^{31}$ To sum up, then: although the finds on the Acrocorinth do provide a ritual context for the placement of curse tablets in the early imperial period, aside from the lamps, little suggests that a mystery cult per se was a crucial part of the setting, rather than simply a place where various underworld forces of punishment could be invoked by placing a lead curse tablet on or into the ground. Access to this sanctuary was, of course, limited to women, and, in fact, nearly all of the victims' names on the tablets are female.

\section{THE GREAT MOTHER}

As was the case on the Acrocorinth, the majority of the curse tablets found at Mainz -24 of the 34 - came from within the sanctuary, in this case one jointly dedicated to Isis and the Great Mother - as a number of inscriptions reveal - and dated to the late Neronian and early Flavian periods. ${ }^{32}$ During this period Mainz was a military town dominated by a legionary fortress, whose troops were drawn primarily from northern Italy and southern Gaul, with at least three auxiliary units from Syria-Palestine. ${ }^{33}$ The sanctuary was placed near a main road running between the fortress and the bridge over the Rhine and was built over a pre-historical burial site, whose mounds were still visible at the time of construction - indeed, as the excavators suggest, this site was

${ }^{30}$ STROUD (n. 23) 109 with $\mathrm{n} .41$ for further bibliography.

${ }^{31}$ Pausanias 2. 4. 6.

${ }^{32}$ All of the information given in the next two paragraphs comes from WITTEYER, M.: Curse Tablets and Voodoo Dolls from Mainz: The Archaeological Evidence for Magical Practices in the Sanctuary of Isis and Magna Mater. In MHNH: Revista internacional de investigación sobre magia y astrología antiguas 5 (2005) 105-124. I will not discuss the three voodoo dolls (one with a small lead strip identifying the victim by name), because they were not found within the sanctuary proper. Two were found in a well and the third on the top layer of a garbage pit that had been reopened to insert the following: a wooden box containing a clay voodoo doll pierced with needles and purposely broken in half and a lead tablet inscribed "Trutmo Florus, son of Clitmo"; a used lamp; and a small pot in which had been burnt fruits such as dates. See WITTEYER for detailed discussion.

${ }^{33}$ WITTEYER (n. 32). 


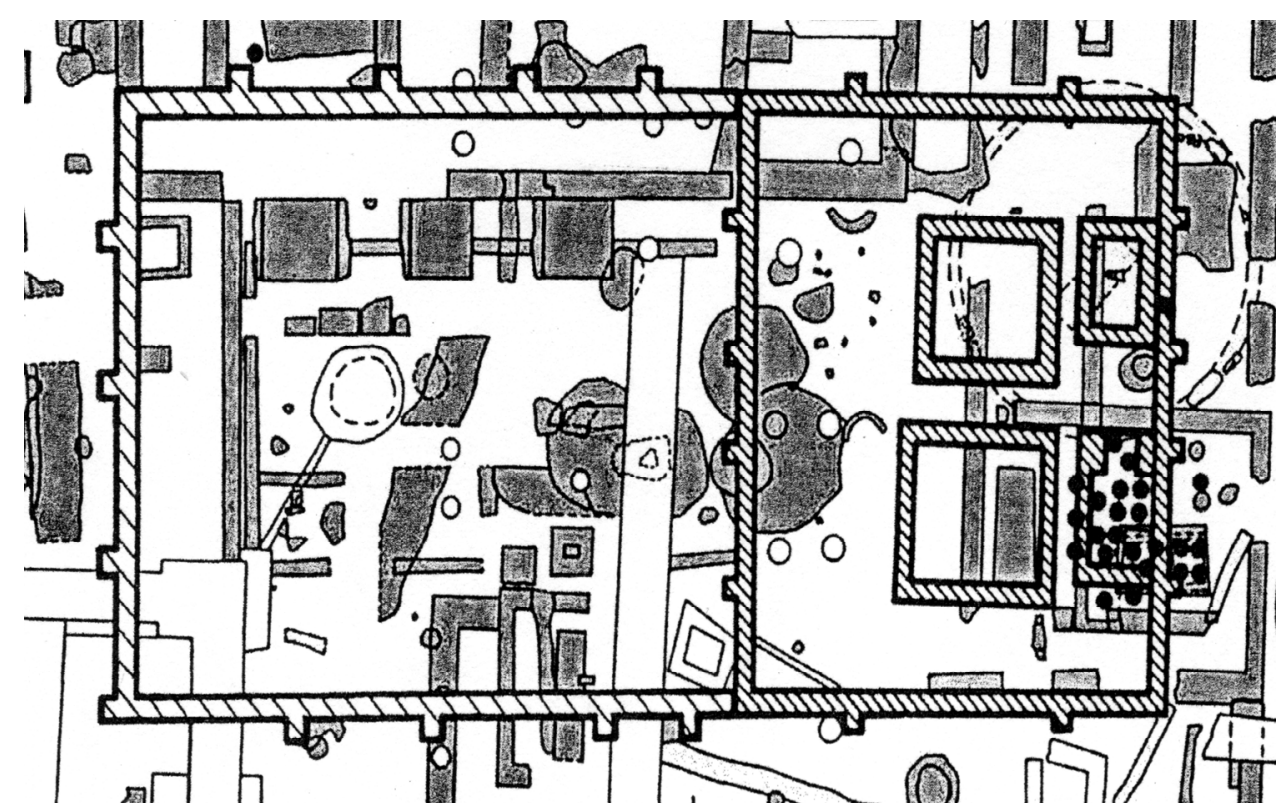

Fig. 4. Plan of the Sanctuary of the Magna Mater in Mainz (WITTEYER [n. 33] 110 fig. 3)

probably chosen for this very reason as an appropriate place for worshipping a pair of goddesses, whose cults included (among other things) ritual laments for a dead husband or consort. The rectangular sanctuary, as you can see in Figure 4, had two square shrines of equal size at its eastern end, with their entrances facing west. Behind each shrine archaeologists found rectangular areas that were used for sacrifice or other kinds of depositions. Because a small altar to Isis was found in a deposit behind the northern shrine, the excavators assumed that this shrine was dedicated to Isis, an idea that was confirmed later, when they discovered in the area behind the southern shrine twenty-four lead curse tablets (marked with black dots on the lower right corner of Figure 4), which invoke Magna Mater and her consort Atthis, but no other deity. These curse tablets, moreover, were placed in a series of rectangular firepits constructed over a fifty-year period, and some of the lead tablets themselves show signs of melting or use a formula that reveals how they were purposely destroyed during the ritual, for example: $:^{34}$

I hand over to you and observing all ritual form ask that you require from Publius Curtius and Piperion the return of the goods entrusted to them. Also Placida and Sacra her daughter: may their limbs melt, just as this lead shall melt, so that it shall be their death.

${ }^{34}$ BlänSDORF, J.: The Defixiones from the Sanctuary of Isis and Magna Mater in Mainz. In GoRDON, R. - MARCO SIMÓN, F. (eds): Magical Practice in the Latin West: Papers from the International Conference held at the University of Zaragoza, 30 Sept. - 1 Oct. 2005. Leiden 2010, 141-190, no 12. 
It seems clear, then, that these fire-pits, like the four altars in Room 7 on the Acrocorinth, were repeatedly the sites of ritual burning and cursing in the early imperial era. The presence, moreover, of numerous lumps of melted lead in the fire-pits at Mainz suggests that the curses were more numerous than the surviving tablets let on.

These ceremonies at Mainz also involved the use of lamps and unguentaria (the latter presumably for pouring libations of oil), as well as offerings of nuts, grains, and fruits (especially figs, grapes, dates, and pine-cones) and the holocaust sacrifice of two types of birds: chickens and song-birds. ${ }^{35}$ Since one of the lead tablets was wrapped around a chicken bone, there may have been a close connection between the killing of birds and the deposition of curses. The use of lamps around open fire-pits suggests, of course, nocturnal rituals, in which the flames of fire would also play an important visual role. And if we assume that the sanctuary was closed to those who were not initiated into the mysteries of Isis or the Mother, there is reason to recall that at the sanctuary of Palaimon at Isthmia, archaeologists also found a series of three (albeit much larger) rectangular fire-pits, one enlarging or replacing the other over a period of years, in which - as was mentioned earlier - they found the bones of completely burnt bulls and lamps designed to burn all night. These burial pits at Isthmia, moreover, were at all stages shielded from the sight of the uninitiated by high walls, just as the fire-rituals at Mainz were performed in a rather narrow space (roughly 3 by 5 meters) between the back of the shrine building and the high sanctuary wall. The fire-pits at Mainz were used one after the other for about fifty years, and then around $130 \mathrm{CE}$ the area was carefully covered and sealed off by a layer of roof-tiles. It was never used again for such ceremonies.

Were these firepits connected with initiation rituals, like those apparently performed around the fire-pit in the sanctuary of Palaimon at Isthmia? A handful of the lead tablets that survived the fires at Mainz do, in fact, refer obliquely to the mystery cult of the Magna Mater and her consort Atthis, as, for example, the curse against a man named Liberalis: ${ }^{36}$

Good, holy Atthis, Lord help (me)! Go to Liberalis in anger! I ask you by everything, lord, by your Castor (and) Pollux, by the cistae in your sanctuary, give him a bad mind, bad death, as long as he lives.... Grant this, I ask you, by your majesty.

Here, as is often the case with these prayers for justice, the curse seems designed to anger the god at some perceived slight, in this case perhaps by mentioning the golden cistae that presumably sat in the inner sanctum of the shrine and allegedly held the god's severed genitals. ${ }^{37}$ Another tablet, discovered in a "sacred pool" in Portugal, refers to the cult of Atthis in similar fashion and suggests that these kinds of curses were not limited to Germany:

\footnotetext{
${ }^{35}$ It is unclear whether these items were burnt up entirely as a holocaust or whether the participants consumed part of the food.

${ }^{36}$ BLÄNSDORF (n. 34) no. 1.

${ }^{37}$ VERSNEL (n. 16).
} 
Unconquered Lord Megarus, you who receive the body of Atthis, may you receive the body of him who robbed me.... I give and donate his body and soul to you, so that I may find my property. I then promise you a fourfooted sacrifice, Lord Atthis, if I find that thief. ${ }^{38}$

Here "unconquered Lord Megarus" refers euphemistically to Pluto, who according to the myth celebrated every March in the sanctuaries of Magna Mater, received the body of Atthis in Hades. The invocation of Atthis himself at the end of the text, as well as the language of donation and sacrifice, clearly suggests that the tablet was designed to be placed in a sanctuary.

Other curses from Mainz make direct references to cultic activities carried out in the sanctuary: ${ }^{39}$

In this tablet I curse Quintus.... Just as the galli or the priests of Bellona have castrated or cut themselves, so may his good name, reputation, ability to conduct his affairs be cut away.... Just as he has cheated me, so may you (deal with him) Magna Mater, and take everything away from him. Just as the tree shall wither in the sanctuary, so may his reputation, good name, ability to conduct his affairs wither. I hand (him) over to you, Lord Atthis, that you may punish him for me.

Here the curse places Atthis in the role of "punisher", like Palaimon in the Athenian curse and like the "Fates Who Exact Justice" in the curses from Acrocorinth.

This curse against Quintus, moreover, uses persuasive analogies to describe how the victim will suffer, analogies that are drawn from the rituals traditionally performed in the sanctuary itself. The galli were not priests of the Magna Mater, of course, but they were a special group of devotees, who castrated themselves in imitation of Atthis. The tree, on the other hand, was cut down and carried in a procession into the sanctuary, where it was allowed to wither and die as part of the ritual. Both the castration and the withering took place in late March, and the use of the future tense to describe the tree - i.e. "just as the tree will wither" - suggests that this particular tablet, at least, may have been inscribed during the festival, and that its author may have even hoped that the victim would visibly wither day by day as the tree was dying in the sanctuary. Such an analogy, of course, would be similar to those already mentioned that request that the victims "melt, just as this lead shall melt!"40 It may be significant, however, that unlike the analogy to melting lead, which used a deictic pronoun to refer to the tablet at hand (i.e. "just as this tablet melts"), the references to the self-castration of the galli or to the withering tree do not use any deictic modifier at all; thus, for example, they say "just as the tree shall wither in the sanctuary" rather

${ }^{38}$ MARCO SimÓN, F.: Magia y cultos orientales: acerca de una défixio de Alcacer do Sal (Setúbal) con mención de Atis. MHNH 4 (2004) 79-94; and TOMLIN, R.: Cursing a Thief in Iberia and Britain. In Gordon, R. - MARCo Simón, F. (eds): Magical Practice in the Latin West: Papers from the International Conference held at the University of Zaragoza, 30 Sept. - 1 Oct. 2005. Leiden 2010, 245-274, no 4. For this translation and discussion, see TOMLIN ibid. and VERSNEL (n. 16) 297-300.

${ }^{39}$ BLÄNSDORF (n. 34) no 18.

${ }^{40}$ BLÄNSDORF (n. 34) no 18. 
than "just as this tree shall wither in this sanctuary". Therefore we should leave open the possibility that these less focused analogies to cultic performances may have simply been inspired by the general knowledge of the rituals performed in the sanctuary, knowledge that was shared between the authors of these curses and the gods they invoked.

The question arises, finally, whether such curses were overseen by the temple personnel in the sanctuary. We saw a similar situation on the Acrocorinth, where the lead tablets were deposited, probably at night, in a narrowly defined and somewhat secret cult place. It is also worth noting that on the Acrocorinth, after an initial period of activity, the cursing rituals in Room 7 come to a halt in the late 2 nd century CE, some fifty years after they stop at Mainz, suggesting perhaps that in both places these rituals were no longer permitted by the priests. In neither case, moreover, do we have any evidence that these curses were inscribed by professional priests or scribes working from handbooks: very few of the hands or the formulas are repeated exactly, and the tablets themselves vary widely in size and shape, all of which suggests numerous agents acting in a traditional, but ad hoc manner.

\section{CONCLUSION}

To conclude briefly, let us look at the comparative chart below:

\begin{tabular}{lll} 
& Pre-Roman & Roman \\
\hline Palaimon & $\begin{array}{l}\text { 4th cent. BCE curse from } \\
\text { Athenian sanctuary }\end{array}$ & $\begin{array}{l}\text { mystery rites, burning } \\
\text { pits, but no curses }\end{array}$ \\
Acrocorinth & $\begin{array}{l}\text { mystery rites, but } \\
\text { no curses }\end{array}$ & $\begin{array}{l}\text { curses and burning } \\
\text { but no mysteries }\end{array}$ \\
Mainz & N/A & $\begin{array}{l}\text { mystery rites, burning } \\
\text { pits, and curses }\end{array}$
\end{tabular}

We can see that, although there are hints of a wider pattern on the Acrocorinth and at the sanctuaries of Palaimon, it is only at Mainz in the Roman period that curses seem to coincide with the performances of mysteries. One feature that all three places share is the curse form known as a "judicial prayer" or "prayer for justice", which invokes gods as judges or punishers of the victim, who is often alleged to have committed a crime of theft or fraud. ${ }^{41}$ But, as is so often the case, we do not possess a full set of data. In the 1950s, archaeologists quickly but fully excavated the Athenian sanctuary in which the Palaimon curse was found, but their report has never been published. One would love to know, of course, whether there was evidence for fire-pits and lamps similar to those used a half-millennium later at his sanctuary in Isthmia.

The parallels between the sanctuaries on the Acrocorinth and at Mainz are, of course, the most suggestive, since each had a secluded spot for such cursing rituals

${ }^{41}$ VERSNEL (n. 16). 
and thus - for a time, at least - seems to have tolerated or even encouraged the practice. But until explicit evidence turns up for mystery celebrations on the Acrocorinth during the Roman period, one must allow that all of the evidence presented here today can just as easily be explained as the attraction of curse rituals to those sanctuaries that were thought to provide, in one way or another, easy access to the often angry punishers in the underworld, be they goddesses who exact justice, like Magna Mater or the Fates, or young men, like Atthis, Opheltes, or Palaimon, who die young and are presumed to be quick to anger.

Christopher A. Faraone

Department of Classics

University of Chicago

USA 
